\title{
Consumption of dissolved organic carbon by marine bacteria and demand for inorganic nutrients
}

\author{
Ulla Li Zweifel, Bo Norrman, Åke Hagström \\ Department of Microbiology, University of Umeå, S-901 87 Umeå, Sweden
}

\begin{abstract}
Seawater cultures were used to study seasonal and diel variations in bacterial growth and nutrient availability. In both the Baltic Sea and the Northeast Mediterranean, the least available component for bacterial growth was phosphorus. In the Baltic Sea, carbon was available in excess for bacterial growth on all sampling occasions. Compared to the controls, additions of nonlimiting concentrations of inorganic nitrogen and phosphorus increased the yield of bacteria compared to the control with $156 \%$ and the degradation of dissolved organic carbon (DOC) by $64 \%$ (as determined by high temperature catalytic oxidation). Analogous, bacterial growth yield increased along with an accumulation of inorganic nutrients in diel experiments with an intact foodweb (microcosm). The concentration of utilizable carbon (UC) was determined from bacterial consumption of DOC in seawater cultures during non-limiting nutrient conditions. Utilizable phosphorus (UP) and utilizable nitrogen (UN) were calculated by converting the bacterial biomass in the cultures into phosphorus and nitrogen equivalents. In the Baltic the average concentrations of UC, UN and UP were found to be $23 \mu \mathrm{M} \mathrm{C}, 0.6 \mu \mathrm{MN}$ and $0.03 \mu \mathrm{M}$ P respectively. Heterotrophic bacteria preferentially utilized inorganic nitrogen and phosphorus to support growth on a short time scale (days). Bacterial carbon content decreased as a result of nutrient additions from $51 \pm 7$ to $32 \pm 5 \mathrm{fg} \mathrm{C}$ cell $^{-1}$ Growth efficiencies varied from 11 to $54 \%$ in untreated cultures compared to 14 to $58 \%$ in cultures supplemented with nitrogen and phosphorus.
\end{abstract}

\section{INTRODUCTION}

Heterotrophic bacteria in the trophic layer of the sea usually encounter a dissolved organic substrate with a surplus of carbon compared to a balanced growth substrate (Williams 1986). Hence, either bacteria must specifically select compounds that are rich in nitrogen and phosphorus or the organic substrate must be supplemented with inorganic $\mathrm{N}$ and $\mathrm{P}$ (Goldman et al. 1987). Inorganic nutrients as limiting factors for bacterial growth have been observed in the Baltic Sea and experiments by Horrigan et al. showed that seawater off Scripps pier (California, USA) could support an increased bacterial biomass when supplemented with inorganic nitrogen (Horrigan et al. 1988, Heinänen \& Kuparinen 1992). Also, Wheeler \& Kirchman showed that the net growth rate of heterotrophic bacteria from the Gulf Stream was significantly higher after the addition of glucose and ammonium compared with an amino acid mixture (Wheeler \& Kirchman 1986). Availability of nutrients has traditionally been viewed to be correlated with algal abundance although bacteria, especially in oligotrophic waters, represent a dominant biomass (Fuhrman et al. 1989, Azam \& Smith 1991). With high turnover rates, heterotrophic bacteria have the potential to compete successfully with algae for dissolved inorganic nutrients (Currie \& Kalff 1984)

Bacterial growth rates generally reach highest levels during summer although measurable substrate levels are low, which means that food transfer through the microbial food web ought to be efficient and tightly coupled. Nevertheless, there are numerous records of diel shifts in most measured parameters, suggesting uncoupling between producers and consumers, and resulting in accumulation of cells 
and metabolic products (Mopper \& Lindroth 1982. Straskrabova \& Fuksa 1982, Hagström \& Larsson 1984, Riemann et al. 1984, Fuhrman et al. 1985, Burney 1986, Hama et al. 1988, Paul et al. 1988, Wikner et al. 1990). Rapid turnover and strong diel variations in nutrient supply may therefore be important factors influencing the short-term (hours) growth conditions for heterotrophic bacteria.

In this study, we investigated how different nutrient conditions may affect bacterial growth and utilization of DOC. Nutrient limitations and instantaneous substrate pools were determined in cut-off experiments (no primary producers or predators) using seawater cultures. Pool sizes of utilizable substrates were determined and compared with in situ turnover of the bacterial community. Bacterial growth conditions were also studied in 2 non-cut-off experiments, using microcosms. These experiments were performed in the Mediterranean Sea with pronounced dark and light cycles. This allowed us to study the effect on bacterial growth of diel changes in the flow of nutrients through the microbial food web.

\section{MATERIALS AND METHODS}

Sampling and seawater cultures. Water was collected at $4 \mathrm{~m}$ depth at NB1 $\left(63^{\circ} 30^{\prime} \mathrm{N}, 19^{\circ} 48^{\prime} \mathrm{E}\right)$, a coastal sampling station in the northern Bothnian Sea. The maximum depth at the station is $24 \mathrm{~m}$ and the salinity ranges between 3 and $6 \%$. On 2 occasions, water was collected at Point $B$ in the bay of Villefranche-sur-Mer $\left(43^{\circ} 41^{\prime} \mathrm{N}, 7^{\circ} 19^{\prime} \mathrm{E}\right)$ in the Mediterranean Sea. Samples were collected using a polycarbonate water sampler and transferred to acid-rinsed polycarbonate bottles.

Sampled water was filtered through $0.2 \mu \mathrm{m}$ filters (Gelman Supor) at $<200 \mathrm{~mm} \mathrm{Hg}$ using acid-washed filtration equipment (Nalgene polysulfone unit or Millipore Sterifile unit) (Ammerman et al. 1984). The first $50 \mathrm{ml}$ was discarded and the remainder was transferred to polycarbonate bottles. Predator-free inocculum was prepared by gravity filtration 3 times through $0.6 \mu \mathrm{m}$ polycarbonate filters (MSI) and added to the cultures to give a 10 -fold dilution of the inocculum (final concentration $5 \times 10^{4}$ to $10 \times 10^{4}$ cells $\mathrm{ml}^{-1}$ ). Cell counts of the inoculum were made under epifluorescent illumination and no predatrors or autofluorescent primary producers could be detrected. DOC does not increase while preparing a $0.6 \mu \mathrm{m}$ filtrate (checked in separate experiment) and since the same water was used for the inoculate and the experiment the DOC in the seawater culture does not change by addition of the inoculate. All filters used in preparing cultures and inoculum were soaked in $1 \mathrm{M} \mathrm{HCl}$ and thereafter extensively rinsed in ultra-pure water (Millipore MilliQ) prior to use.

The cultures were incubated in the dark at in situ temperature except for cultures prepared in 1991 which were all cultured at $15^{\circ} \mathrm{C}$ (the in situ temperature ranged between 5 and $15^{\circ} \mathrm{C}$ ).

Nutrient additions. Cultures were prepared as described above. Bacterial numbers in the cultures were monitored and the water was divided into 4 subsamples when growth rates started to decline. The subsamples were treated as follows: (1) no further treatment, (2) ammonium addition, (3) phosphate addition, (4) phosphate and ammonium addition. The cultures were sampled for bacterial numbers and DOC at regular time intervals. When stationary phase was reached the cultures were sampled for nutrients and POC. Parallel experiments with nutrient additions immediately after inoculation gave identical results.

Nutrients were added to give an enrichment of $0.6 \mu \mathrm{M} \mathrm{PO}_{4}-\mathrm{P}\left(\mathrm{Na}_{2} \mathrm{HPO}_{4}\right)$ and $2 \mu \mathrm{M} \mathrm{NH}-\mathrm{N}\left(\mathrm{NH}_{4} \mathrm{Cl}\right)$ which approximates inorganic nutrient concentrations at NB1 during unstratified winter conditions. Phosphate and ammonium concentrations were measured at the start and end of the incubations. The remaining amount of the added nutrient $\left(\geq 1.5 \mu \mathrm{M} \mathrm{NH} \mathrm{NH}_{4}\right.$ and $\geq 0.5 \mu \mathrm{M} \mathrm{PO}_{4}$ ) confirmed that the added nutrient never became limiting for growth. All solutions used were cross-checked for inorganic nutrient and organic carbon contamination. Carbon additions were only performed in Villefranche-sur-Mer in September 1992. Sucrose was added to increase the DOC concentration by $80 \mu \mathrm{M}$ which equals approximately a $60 \%$ increase in this area.

Microcosm experiment. Microcosm experiments were performed in Villefranche-sur-Mer in September 1984 and 1992. Seawater was prefiltered through a $150 \mu \mathrm{m}$ net in order to eliminate large zooplankton and thereafter transferred to acid-rinsed and seawaterrinsed bottles $(50 \mathrm{l}$ glass 1984,10 l polycarbonate 1992). The bottles were monitored every $3 \mathrm{~h}$ for bacterial and flagellate numbers, ammonium and phosphate concentrations, DOC (1992 only) and yield on $0.2 \mu \mathrm{m}$ filtered water (Hagström et al. 1988).

Bacterial and flagellate enumeration. Samples for bacterial and flagellate enumeration were preserved with $0.2 \mu \mathrm{m}$ filtered formaldehyde. 5 to $10 \mathrm{ml}$ of the samples were used for counting bacteria either by DAPI or acridine orange staining and 10 to $20 \mathrm{ml}$ was used for counting flagellates by proflavin staining (Hobbie et al. 1977, Porter \& Feig 1980, Haas 1982). Cyanobacteria were counted by autofluorescence. Cells were counted in an epifluoresence microscope (Zeiss Universal). At least 20 fields and 200 objects were counted for bacterial enumeration and 40 fields for flagellates. 
Bacterial production. Bacterial production was measured using the $\left[{ }^{3} \mathrm{H}\right]$ thymidine incorporation method (Fuhrman \& Azam 1982). Samples were incubated for $1 \mathrm{~h}$ with $10 \mathrm{nM}\left[{ }^{3} \mathrm{H}\right]$ thymidine (final concentration) under in situ conditions. A conversion factor of $1.7 \times 10^{18}$ cells per mole $\left[{ }^{3} \mathrm{H}\right]$ thymidine was used to convert moles of incorporated thymidine to number of produced cells.

Dissolved organic carbon (DOC). DOC samples were filtered through $0.2 \mu \mathrm{m}$ filters (Gelman Supor) using disposable syringes (Terumo) connected to filter holders (Millipore) or by use of polycarbonate filtration units (Nalgene). $7.5 \mathrm{ml}$ of filtered water was transferred to polypropylene test tubes (Falcon, $15 \mathrm{ml}$ ), immediately acidified with $100 \mu \mathrm{l} 1.2 \mathrm{M} \mathrm{HCl}$ and kept at $+4{ }^{\circ} \mathrm{C}$ until analysis. All materials in contact with the samples, including the filters and filter units, were carefully acid-rinsed with $1 \mathrm{M} \mathrm{HCl}$ and washed with ultra-pure water (Millipore Milli-Q) prior to use. DOC was measured with a high temperature carbon analyzer (Shimadzu TOC 5000) using a 4-point calibration curve with potassium biphthalate as standard. Standard solutions were run at each analysis in order to check for instrumental shifts. Blanks were tested before each analysis by injection of ultra-pure water (Millipore Milli-Q). The total blank (water + system blank) was in all cases less than $0.1 \mathrm{mg}^{1^{-1}}$. Samples were not corrected for this blank. Triplicate injections showed standard deviations of 0 to $2 \%$. In most cases at least 2 individually filtered samples were analysed and showed standard deviations of 0 to $1 \%$ from the mean value of triplicate injections. The detection limit of the system for $\mathrm{DOC} \approx 100 \mathrm{nM}$.

Particulate organic carbon (POC). Samples of 200 to $500 \mathrm{ml}$ from the seawater cultures were filtered through precombusted $\left(30 \mathrm{~min}, 200^{\circ} \mathrm{C}\right) 0.2 \mu \mathrm{m}$ silver filters (Poretics) at maximum $200 \mathrm{~mm} \mathrm{Hg}$. Blanks were prepared by filtering particle-free media onto precombusted filters. The total blank (filter + nonspecific adhesion of $<0.2 \mu \mathrm{m}$ organic material) made up 3 to $10 \%$ of the total sample (filter + nonspecific adhesion of $<0.2 \mu \mathrm{m}$ organic material + sample) and was subtracted. The filters were air-dried and thereafter stored frozen prior to analysis with a C.HN analyser (Carlo Erba).

Nutrient measurements. Nutrient determinations in 1984 were performed using standard methods according to Strickland \& Parsons (1972) and in 1991 and 1992 with an autoanalyzer (Technicon TRAACS 800). Dissolved organic nitrogen (DON) was calculated from measurements of total nitrogen in filtered samples minus the sum of inorganic nitrogen. Dissolved organic phosphorus (DOP) was calculated accordingly. The detection limit of the system for dissolved inorganic phosphorus (DIP) $\approx 10 \mathrm{nM}$; dissolved inorganic nitrogen $(\mathrm{DIN})=30 \mathrm{nM}$.

\section{RESULTS}

\section{Seawater cultures}

Bacterial growth was followed in a number of seawater batch cultures during 1991 and 1992. Filtered $(<0.2 \mu \mathrm{m})$ seawater was inoculated with ambient bacteria from the coastal station NB1. The cultures were used to assay the number of bacteria that can be supported by $0.2 \mu \mathrm{m}$ filtered seawater and thus the pool of dissolved utilizable substrates. In the text, this assay is referred to as yield of bacteria. The bacteria showed a classical sigmoid growth pattern (Fig. 1). After a lag phase that varied between 10 to $40 \mathrm{~h}$, bacteria grew with a generation time of 12 to $32 \mathrm{~h}$ and reached stationary phase within $120 \mathrm{~h}$. The bacterial consumption of dissolved organic carbon varied between 1 and $7 \%$ of the total DOC (data not shown). To check if the seawater was contaminated by the filtration procedure, inorganic nutrients and organic carbon were measured before and after filtration. No measurable contaminants could be found within the precision of our methods. In order to further establish the reproducibility of the assay system, we duplicated the cultures on 3 occasions. The results showed only minor deviations in bacterial yield and DOC consumption (Table 1).

Periodic sampling at NB1 showed a seasonal variation in the yield of bacteria (Fig. 2). The number of ambient bacteria, reflecting the carrying capacity of the seawater (as defined in Begon et al. 1986), exceeded the yield of bacteria on all but 2 occasions

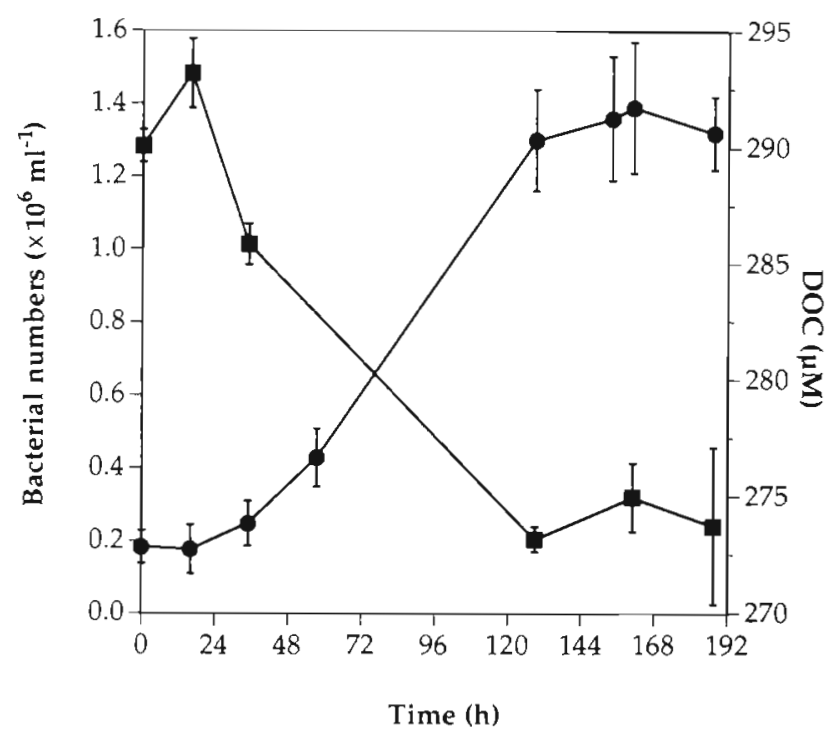

Fig. 1. Growth of a mixed marine bacterial assemblage in particle-free seawater. (-) Bacterial numbers. ( Concentration of dissolved organic carbon (DOC), mean of duplicated filtrations. Error bars: SD 
Table 1. Comparison of bacterial growth and DOC consumption between duplicate predator-free seawater cultures. Cultures (2l) were incubated at $15^{\circ} \mathrm{C}$ for $120 \mathrm{~h}$

\begin{tabular}{|c|c|c|}
\hline Date & $\begin{array}{l}\text { Yield of bacteria } \\
\left(\text { cells } \times 10^{6} \mathrm{ml}^{-1}\right)^{d}\end{array}$ & $\begin{array}{l}\text { Consumption } \\
\text { of DOC }(\mu \mathrm{M})^{b}\end{array}$ \\
\hline \multicolumn{3}{|c|}{ April 9. 1992} \\
\hline Culture I & $0.51 \pm 0.05$ & $20 \pm 0.2$ \\
\hline Culture II & $0.53 \pm 0.05$ & $20 \pm 0.2$ \\
\hline \multicolumn{3}{|c|}{ April 14, 1992} \\
\hline Culture I & $0.50 \pm 0.08$ & $13 \pm 0.2$ \\
\hline Culture II & $0.55 \pm 0.06$ & $15 \pm 0.1$ \\
\hline \multicolumn{3}{|c|}{ April 21, 1992} \\
\hline Culture I & $1.19 \pm 0.11$ & $19 \pm 0.2$ \\
\hline Culture II & $1.08 \pm 0.08$ & $17 \pm 0.2$ \\
\hline \multicolumn{3}{|c|}{$\begin{array}{l}\text { "Measured as direct counts of bacteria, mean value of } \\
>20 \text { fields of observation } \pm \text { SD }\end{array}$} \\
\hline \multicolumn{3}{|c|}{${ }^{\mathrm{b}}$ Mean value of 3 samples $\pm \mathrm{SD}$} \\
\hline
\end{tabular}

(April 1991). Yield was lowest in July and August although the concentration of DOC reached a maximum. The concentration of DOC increased from April to July during both 1991 and 1992 with $60 \mu \mathrm{M}$ and $90 \mu \mathrm{M}$ carbon respectively. Since nutrients generally are low during summer, this suggested a demand for a substrate component other than carbon and the assay therefore was expanded to include enrichments with inorganic nutrients in 1992.

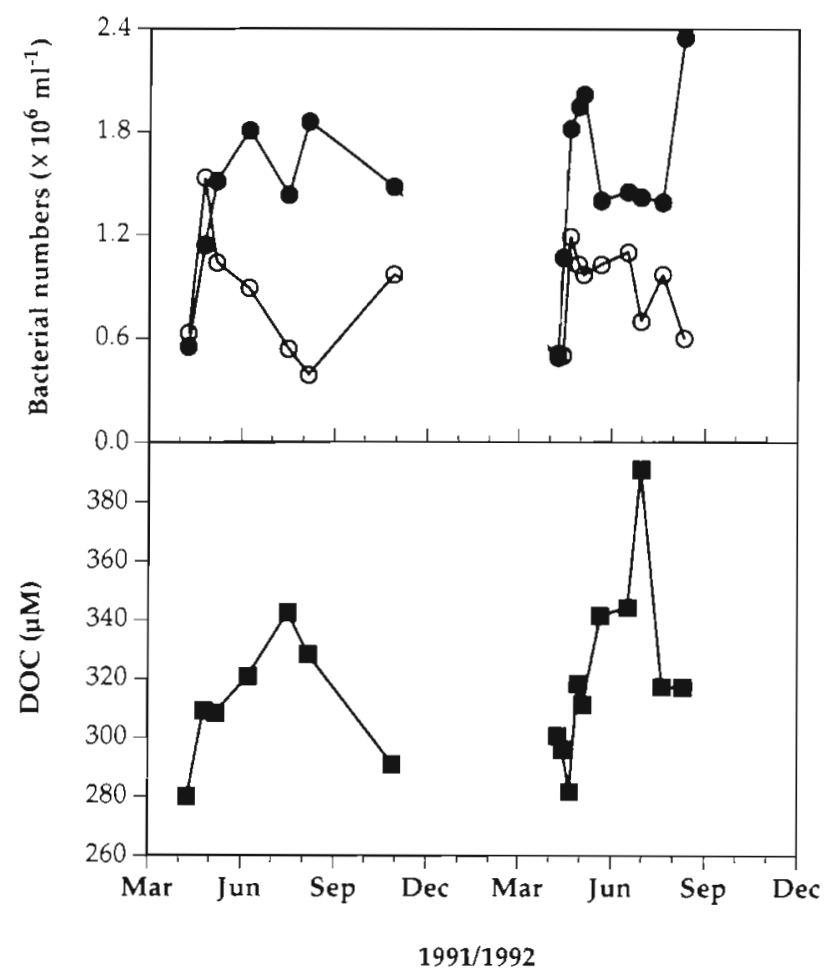

Fig. 2. Seasonal variation in yield of bacteria grown on $0.2 \mu \mathrm{m}$ filtered seawater, compared to bacterial numbers and dissolved organic carbon (DOC) at the sampling site NB1. (O) Bacterial yield; ( $\bullet$ in situ number of bacteria; ( $\bullet$ in situ DOC
Table 2. Growth of mixed heterotrophic bacteria in seawater cultures with the addition of inorganic nutrients. Untreated and enriched seawater cultures from the Baltic station NB1 were compared over the experimental period April to August 1992 (dates as in Fig. 2)

\begin{tabular}{|c|c|c|c|c|}
\hline & \multicolumn{4}{|c|}{ Treatment } \\
\hline & Untreated & N-enriched & P-enriched & N\&P-enriched \\
\hline $\begin{array}{l}\text { Yield of bacteria } \\
\text { (cells } \times 10^{6} \mathrm{ml}^{-1} \text { ) }\end{array}$ & $0.9 \pm 0.1$ & $0.9 \pm 0.1$ & $1.5 \pm 0.1$ & $2.3 \pm 0.4$ \\
\hline $\begin{array}{l}\text { Carbon consumption } \\
\text { (DOC) }(\mu \mathrm{M})\end{array}$ & $14 \pm 1.5$ & $15 \pm 1.9$ & $17 \pm 2.5$ & $23 \pm 2.8$ \\
\hline $\begin{array}{l}\text { Particulate carbon }{ }^{\mathrm{C}} \\
(\mathrm{POC})\left(\mathrm{fg} \mathrm{C}_{\mathrm{C}} \mathrm{cell}^{-1}\right)\end{array}$ & $51 \pm 7$ & $57 \pm 12$ & $28 \pm 8$ & $32 \pm 5$ \\
\hline $\begin{array}{l}\text { Growth efficiency } \\
\text { (range) }(\%)\end{array}$ & $\begin{array}{c}27 \\
(11-54)\end{array}$ & $\begin{array}{c}29 \\
(11-55)\end{array}$ & $\begin{array}{c}21 \\
(12-40)\end{array}$ & $\begin{array}{c}27 \\
(14-58)\end{array}$ \\
\hline \multicolumn{5}{|c|}{ 'Mean values \pm standard deviation $(n=10)$} \\
\hline \multicolumn{5}{|c|}{$\begin{array}{l}{ }^{b} U \text { tilizable carbon (UC) measured as consumption of DOC in N\&P-enriched } \\
\text { cultures. Mean values of all experiments } \pm \text { standard deviation }\end{array}$} \\
\hline \multicolumn{5}{|c|}{$\begin{array}{l}\text { "Bacteria in seawater cultures collected on } 3 \text { accasions on } 0.2 \mu \mathrm{m} \text { Ag-filters, } \\
\text { mean values } \pm \text { standard deviation }(n=3)\end{array}$} \\
\hline \multicolumn{5}{|c|}{${ }^{\mathrm{d}}$ Growth efficiency calculated as [(Yield $\times$ POC)/DOC consumption] } \\
\hline
\end{tabular}

During the productive season of May to September 1992, the available substrate in the particle-free seawater allowed a significant growth yield of bacteria (Table 2). Since the ambient number of bacteria represents the carrying capacity in the system we related the growth yield in the cultures to the ambient number of bacteria. This ratio is referred to as Growth Capacity [(yield in cultures/ambient number of bacteria) $\times 100$ ]. Untreated and nitrogen-enriched seawater cultures reached a growth capacity of $56 \%$. Addition of phosphate enhanced the growth capacity to on average $94 \%$, and the addition of both ammonium and phosphate increased the growth capacity of the seawater to $144 \%$ suggesting that carbon or an unknown micronutrient became depleted. If carbon is the limiting factor this must be due to poor quality, since DOC was still found in excess in the cultures (average consumption 1 to 
Table 3. Composition and amount of available and utilizable dissolved carbon, nitrogen and phosphorus compared to the composition of marine bacteria at the Baltic station NB1. Mean values \pm standard error $(n=10)$

\begin{tabular}{|c|c|c|c|c|}
\hline & \multicolumn{4}{|c|}{ Elemental composition } \\
\hline & $\mathrm{C}(\mu \mathrm{mol})$ & $N(\mu \mathrm{mol})$ & $\mathrm{P}(\mu \mathrm{mol})$ & Ratio of $C: N: P$ \\
\hline Bacteria $\left(\text { cell }{ }^{-1}\right)^{a}$ & $1.7 \times 10^{-9}$ & $4 \times 10^{-10}$ & $3.8 \times 10^{-11}$ & $45: 10: 1$ \\
\hline Available organic $\left(1^{-1}\right)$ & $320 \pm 9.3$ & $13 \pm 3.0$ & $0.13 \pm 0.25$ & $2460: 100: 1$ \\
\hline Available inorganic $\left(\mathrm{l}^{-1}\right)$ & - & $0.56 \pm 0.09$ & $0.035 \pm 0.007$ & $-: 16: 1$ \\
\hline Residual inorganic $\left(1^{-1}\right)^{b}$ & - & $0.10 \pm 0.03$ & $<0.009 \pm 0$ & \\
\hline Utilizable $\left(1^{-1}\right)$ & $23 \pm 2.8$ & $0.60 \pm 0.05^{c}$ & $0.033 \pm 0.003^{c}$ & $697: 18: 1$ \\
\hline \multicolumn{5}{|c|}{${ }^{a}$ Calculated from a C:N:P ratio of 45:10:1 and a mean cell carbon of $20 \mathrm{fg} \mathrm{C}$ cell $^{-1}$ for marine bacteria } \\
\hline \multicolumn{5}{|c|}{$\begin{array}{l}\text { 'Residual inorganic nitrogen in phosphate-enriched cultures and residual inorganic phosphorus in ammonia-enriched } \\
\text { cultures }\end{array}$} \\
\hline \multicolumn{5}{|c|}{${ }^{\mathrm{C} C a l c u l a t e d}$ from yield of bacteria assuming $100 \%$ assimilation of $\mathrm{N}$ and $\mathrm{P}$} \\
\hline
\end{tabular}

$7 \%$ ). All in all, the yield of bacteria indicated that the least available component in the seawater was phosphorus followed by nitrogen and carbon.

The consumption of DOC increased from $14 \mu \mathrm{M} \mathrm{C}$ in untreated cultures to $23 \mu \mathrm{M} \mathrm{C}$ when nitrogen and phosphorus were added to the cultures (Table 2). POC varied considerably between limited and nonlimited cells (Table 2). This means that although the carbon consumption per produced cell (DOC consumption/ yield of bacteria) was $56 \%$ higher for limited cells, the growth efficiency [(yield of bacteria $\times$ POC) / DOC consumption] did not differ much between the cultures. (Table 2).

The concentrations of inorganic phosphorus and ammonium were measured at the start and end of all cultures during 1992. The concentrations of available nutrients (start in untreated cultures) and residual concentration of limiting nutrient in enriched cultures (nitrogen in phosphate-enriched cultures and phosphorus in ammonium-enriched cultures) are shown in Table 3

In order to estimate the pool sizes of utilizable substrates, we converted the yield of bacteria in the cultures into nitrogen and phosphorus equivalents. As inorganic nitrogen $\left(\mathrm{NH}_{4}{ }^{+}\right)$never stimulated growth of bacteria, the yield in the nitrogen-enriched cultures was regarded as a reflection of the pool of utilizable phosphorus (UP). Furthermore, the yield in phosphorusenriched cultures was considered as the pool of utilizable nitrogen (UN) since carbon limitations were not reached in these cultures. The nitrogen and phosphorus content of bacteria, used to convert the bacterial yield into phosphorus and nitrogen equivalents $(4.0 \times$ $10^{-16} \mathrm{~mol} \mathrm{~N}$ cell ${ }^{-1}$ and $3.8 \times 10^{-17} \mathrm{~mol} \mathrm{P}$ cell $^{-1}$ ), were obtained from a bacterial C:N:P ratio of $45: 10: 1$ and a mean cell carbon of $20 \mathrm{fg} \mathrm{C}$ cell $^{-1}$ for marine bacteria (Goldman et al. 1987, Lee \& Fuhrman 1987, Neidhardt et al. 1990). As carbon never became limiting for growth in this study, we have considered the relatively high POC values determined in this paper to reflect a storage of carbon and this should not affect the bacterial content of nitrogen and phosphorus. Furthermore, high POC values were determined in cultures where phosphorus was limiting, hence it does not seem likely that $\mathrm{P}$ should be stored in these bacteria. The utilizable pool of carbon (UC) was determined as the consumption of DOC in the cultures with non-limiting $\mathrm{N}$ and $\mathrm{P}$ conditions. The pools of UC, UN and UP are summarized in Table 3 . The available dissolved organic matter (DOC, DON, DOP) at NB1 was found to be highly enriched in carbon compared to the utilizable substrate (Table 3).

\section{Annual growth dynamics}

The final yield in the untreated seawater cultures never exceeded the standing stock of bacteria during 1992 (Fig 2). This result suggested that the ambient bacteria can at most divide once without the substrate pool being replenished. It was therefore of interest to analyze the daily uptake of substrate in relation to the calculated pool size of utilizable nutrients. The in situ phosphate concentration ranged between 0.020 and $0.087 \mu \mathrm{M}$ and the ammonium concentration between 0.21 and $1.16 \mu \mathrm{M}$ with minimum concentrations in June and July (Fig. 3). Starting from a low level $(2.1 \times$ $10^{8}$ cells $\mathrm{l}^{-1} \mathrm{~d}^{-1}$ ) in April, bacterial production reached the annual maximum at the beginning of June $(8.1 \times$ $10^{8}$ cells $\mathrm{l}^{-1} \mathrm{~d}^{-1}$ ). The average bacterial production during the experimental period corresponded to $4.4 \times 10^{8}$ cells $1^{-1} \alpha^{-1}$ and a daily uptake of $0.017 \mu \mathrm{M}$ phosphorus and $0.18 \mu \mathrm{M}$ of nitrogen (calculated from the data of bacterial content in Table 3). The ambient number of 


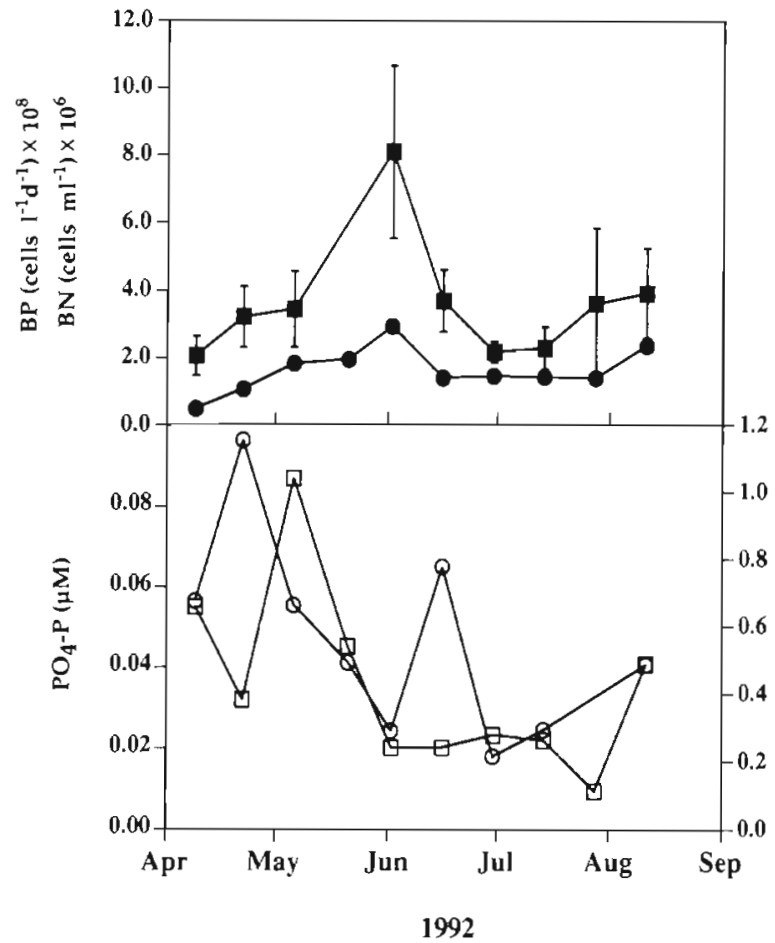

Fig. 3. Bacterial and nutrient dynamics in the surface water $(4 \mathrm{~m})$ of the coastal station NB1. (a) Bacterial production using $\left[{ }^{3} \mathrm{H}\right]$ thymidine uptake (error bars $=\mathrm{SD}$ of triplicate samples); ( ) bacterial numbers (same as Fig. 2); (O) ammonium

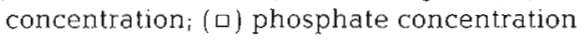

bacteria varied between $0.5 \times 10^{9}$ and $2.9 \times 10^{9}$ cells l$^{-1}$,

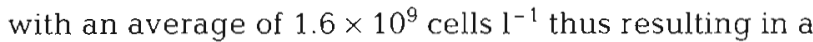
turnover time (calculated from the $\mathrm{P} / \mathrm{B}$ ratio) of $3.6 \mathrm{~d}$. Consequently $30 \%$ of the bacteria must be grazed or lysed each day in order to maintain a constant standing stock.

\section{Diel growth dynamics}

Growth and grazing of $30 \%$ of the standing stock of bacteria each day suggests a rapid cycling of nutrients. Diel growth dynamics in the microbial food web were therefore studied in microcosm experiments. These experiments were performed in the Northeast Mediterranean in September 1984 and 1992. In this area, the stable weather conditions and pronounced day/night cycle combine to synchronize the growth pattern. Fig. 4 shows the concentration of ammonium and phosphate and bacterial yield in $0.2 \mu \mathrm{m}$ filtered water from the microcosms. Diel variations of phosphate, ammonium and bacterial yield were observed in both years. While the phosphate concentration was 5 -fold higher during the 1984 experiment, the same general diel pattern was found. A 1-way ANOVA test confirmed a systematic variation with time $(p>0.016)$. This was also the case for diel variation of bacterial yield $(p>0.011)$. The ammonium concentration peaked in the afternoon and was lowest during early morning although the comparison between years did not suggest the variation to be systematic $(p>0.742)$. Using a multiple regression test on the 1984 and 1992 experiments, the variation in $\mathrm{NH}_{4}$ and $\mathrm{PO}_{4}$ could explain $35 \%(p>0.18)$ and $69 \%(p>0.017)$ of the change in bacterial yield for the respective year. In the 1992 experiment, DOC was included in the measurements showing a diel variation between 111 and $124 \mu \mathrm{M}$. Extending the multiple regression to include DOC showed that $89 \%$ of the variation in bacterial yield could be explained by the variation in phosphate, ammonia and DOC $(p>0.003)$.

In 1984, flagellates and cyanobacteria increased during the night. Flagellate numbers increased from $1.2 \times 10^{3}$ to $3.7 \times 10^{3} \mathrm{ml}^{-1}$, cyanobacteria from $1.1 \times 10^{4}$

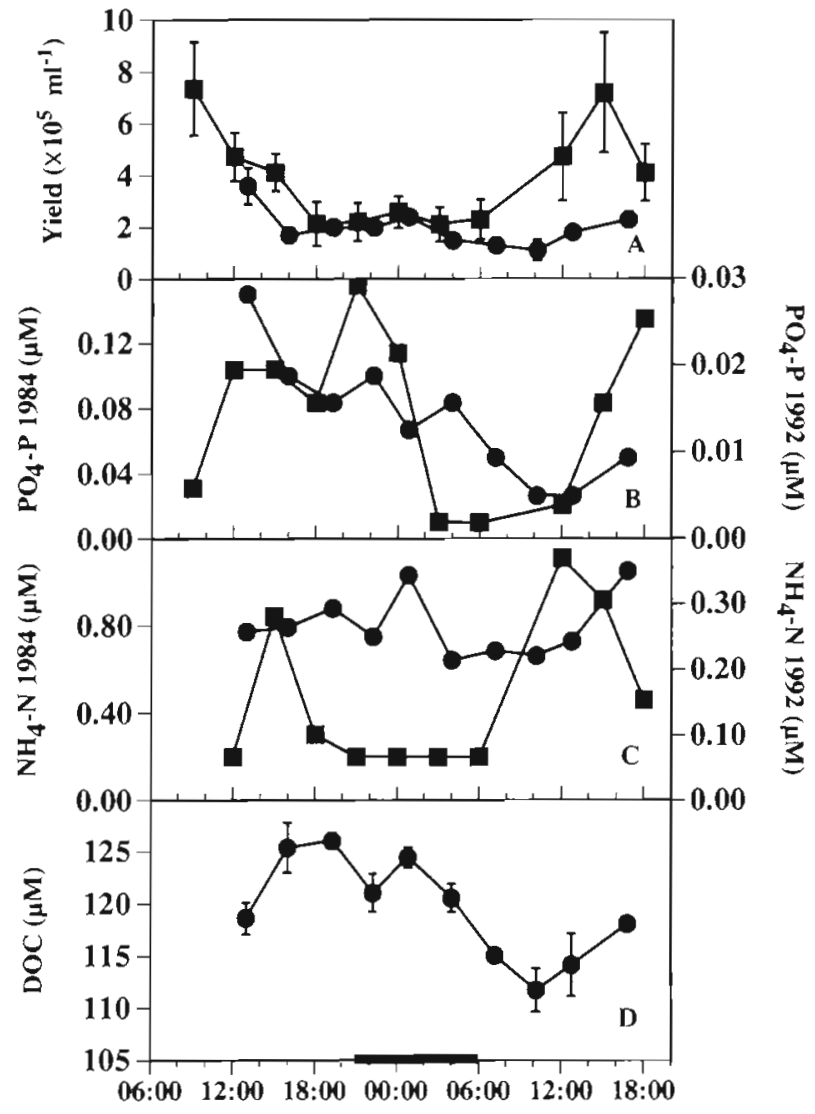

Time

Fig. 4. Diel variations in a Mediterranean microcosm. (A) Bacterial yield on $0.2 \mu \mathrm{m}$ filtered seawater. $(B, C)$ Inorganic nutrients. (D) Dissolved organic carbon. Measurements were performed in $50 \mathrm{l}$ microcosms at ambient light and temperature conditions. (ロ) 1984; (•) 1992 


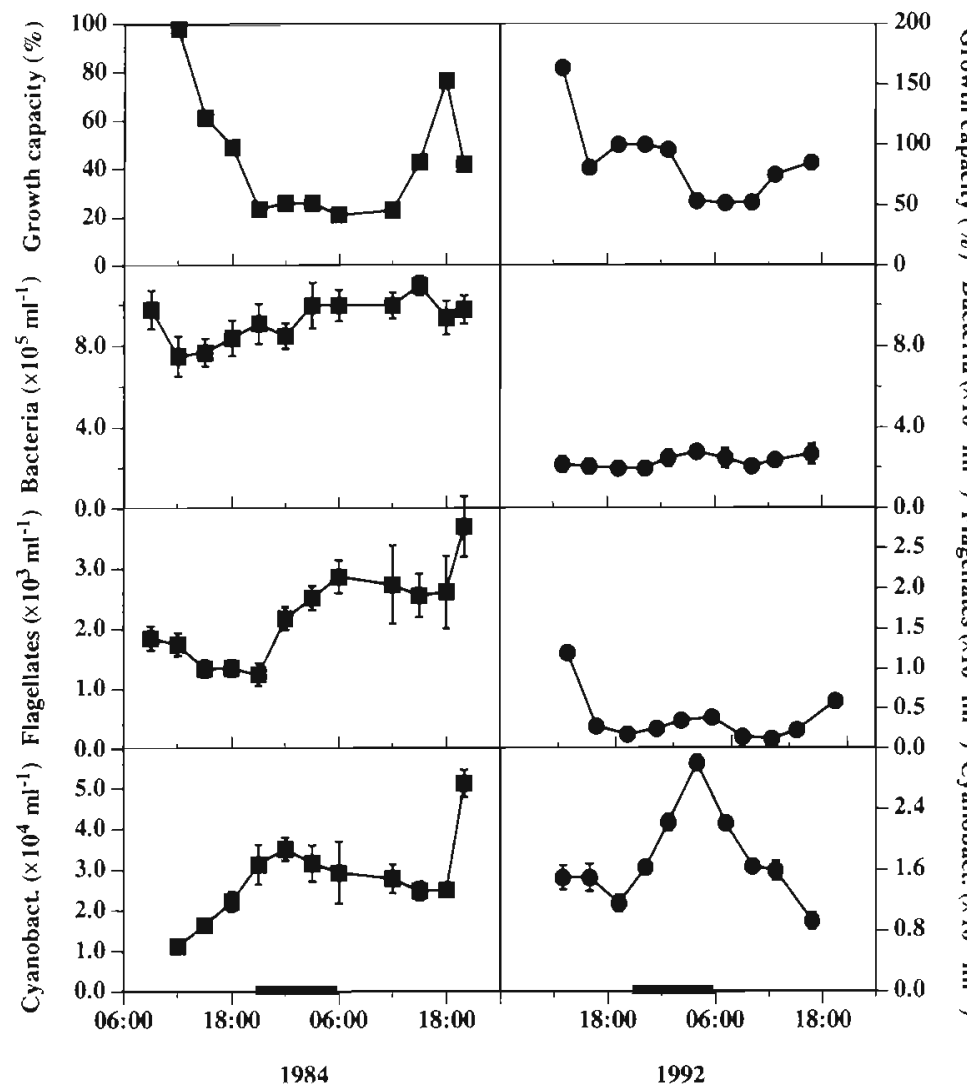

Fig. 5. Diel variation in growth capacity and major organisms in the microbial food web. Measurements were made in the same microcosms as depicted in Fig. 4. Data for 1984 were redrawn from Hagström et al. (1988) determined in seawater cultures. Samples were collected at noon and midnight and enriched with ammonium, phosphate or sucrose (Table 4). Untreated, ammoniumenriched and carbon-enriched samples supported growth of bacteria corresponding to $108 \%$ of the standing stock of bacteria at noon and $152 \%$ at midnight. Additions of phosphate increased the growth yield to $296 \%$ at noon and $291 \%$ at midnight. Addition of both ammonium and phosphate did not increase the yield further. Thus, the data suggests that phosphorus was the least available component for bacterial growth in the Villefranche bay, followed by carbon and nitrogen. The DOC consumption during the incubations was determined in both experiments. The amount of consumed carbon per cell showed only minor differences between the treatments except when sucrose was added, in which case an additional $300 \%$ of the DOC disappeared in the filtrate.

\section{DISCUSSION}

In this study, we used seawater cultures to investigate seasonal and diel variations in bacterial growth and nutrient availability. At the Baltic coastal station NB1, phosphorus was found to be the least available to $5.1 \times 10^{4} \mathrm{ml}^{-1}$ and the numbers of bacteria from $0.21 \times 10^{6}$ to $0.73 \times 10^{6}{\text { cells } \mathrm{ml}^{-1}}^{-1}$ (Fig. 5). The growth capacity of the seawater decreased markedly during the night to support only $20 \%$ of the standing stock.

In the second experiment (1992), the flagellate numbers were low throughout the experiment ranging between $1.2 \times 10^{2}$ and $12 \times 10^{2} \mathrm{ml}^{-1}$, showing the same growth pattern as in 1984. Cyanobacteria counts increased from $0.9 \times 10^{4}$ to $3.0 \times 10^{4}$ cells $\mathrm{ml}^{-1}$ and the numbers of bacteria ranged between $0.20 \times 10^{6}$ and $0.28 \times 10^{6}$ cells $\mathrm{ml}^{-1}$. Both heterotrophic bacteria and cyanobacteria reached maximum numbers during the dark hours. The bacterial growth capacity decreased during the night to $50 \%$ of the standing stock.

The least available component for bacterial growth in the Villefranche bay was
Table 4. Enrichment studies, Villefranche, 1992. Volume of cultures $200 \mathrm{ml}$ incubated at in situ temperature for $72 \mathrm{~h}$

\begin{tabular}{|ccccc|}
\hline Date and treatment & $\begin{array}{c}\mathrm{PO}_{4} \\
(\mu \mathrm{M})\end{array}$ & $\begin{array}{c}\mathrm{NH}_{4} \\
(\mu \mathrm{M})\end{array}$ & $\begin{array}{c}\text { Bacterial } \\
\text { yield } \pm \mathrm{SD} \\
\left(\times 10^{6} \mathrm{ml}^{-1}\right)\end{array}$ & $\begin{array}{c}\text { Growth } \\
\text { capacity } \\
(\%)\end{array}$ \\
\hline In situ Sep 15, 12:00 h & $<0.009$ & 0.26 & $(0.25 \pm 0.08)^{\mathrm{a}}$ & - \\
Enrichment control & & & $0.27 \pm 0.05$ & 108 \\
Enrichment $\mathrm{N}$ & & $0.32 \pm 0.07$ & 128 \\
Enrichment C & & $0.30 \pm 0.05$ & 120 \\
Enrichment P & & $0.74 \pm 0.12$ & 296 \\
Enrichment N and P & & & $0.74 \pm 0.04$ & 296 \\
& & & - \\
In situ Sep 15, 24:00 h & 0.016 & 0.25 & $(0.23 \pm 0.05)^{\circ}$ & - \\
Enrichment control & & & $0.35 \pm 0.04$ & 152 \\
Enrichment N & & & $0.39 \pm 0.06$ & 171 \\
Enrichment C & & & $0.33 \pm 0.04$ & 143 \\
Enrichment P & & & $0.67 \pm 0.11$ & 291 \\
Enrichment N and P & & & $296 \pm 0.10$ & 296 \\
an situ numbers of bacteria & & & \\
\hline
\end{tabular}


component for bacterial growth, followed by nitrogen and carbon. The in situ dissolved organic matter (DOM) in the surface water was far from ideal as a bacterial substrate. (Table 3 ). With a C:N:P ratio of $2460: 100: 1$, it was high in carbon but low in phosphorus when compared to a more typical marine area (Southern California Bight) with a $\mathrm{C}: \mathrm{N}: \mathrm{P}$ ratio of $400: 28: 1$ (Table 3) (Williams 1986). From the seawater cultures the average concentrations of utilizable carbon, nitrogen, and phosphorus were estimated to be $23 \mu \mathrm{M} \mathrm{C}, 0.6 \mu \mathrm{MN}$, and $0.03 \mu \mathrm{M}$ P respectively. The ratio of utilizable components (UC:UN:UP), including both inorganic nutrients and dissolved organic matter, was 697:18:1. Relative to carbon, the utilizable substrate was richer in phosphorus but poorer in nitrogen, compared to the in situ DOM at NB1.

Our results suggest that over a time scale of days, bacteria preferentially used inorganic sources of nitrogen and phosphorus to support growth. Ammonium and phosphate were measured at the start and end of all enrichment experiments showing that the DIP always dropped below the detection limit $(<0.009 \mu \mathrm{M})$ in the ammonium-enriched cultures while DIN in phosphate-enriched cultures decreased by $82 \%$. Thus, $\geq 79 \%$ of the phosphorus found in bacterial biomass could be explained by the decrease in DIP while $77 \%$ of the nitrogen in bacterial biomass could be explained by the decrease in DIN (Table 3). Goldman et al. (1987) showed that $\mathrm{NH}_{4}{ }^{+}$-regeneration of organic nitrogen is only found when the $\mathrm{C}: \mathrm{N}$ ratio of the substrate is $\langle 10: 1$, a ratio that is rarely met in nature. Our reults also indicate that bacteria are inefficient remineralizers of $\mathrm{N}$ and $P$.

The pool of UN may include peptides and amino acids as well as inorganic nitrogen. Compared to the pool of UN $(0.6 \mu \mathrm{MN})$, the amount of dissolved free amino acids (DFAAs) in the Baltic has been shown to vary within a range of 30 to $400 \mathrm{nM}$ corresponding to 0.03 to $0.45 \mu \mathrm{M} \mathrm{N}$ (Mopper \& Lindroth 1982). This means that 5 to $75 \%$ of UN may be supported by DFAAs. In the case of organic phosphorus, phosphate must be enzymatically cleaved from the carbon skeleton before being assimilated by the cell (Ammerman \& Azam 1991). DOP is thereby channelled into DIP, and available phosphorus is determined by the concentration of inorganic phosphate. Nucleic acids are found in significant amounts in the DOP and have been shown to be rapidly degraded (Turk et al. 1992). Our results, which indicate a strong coupling between inorganic nutrients and DOC degradation, are therefore puzzling since both the DON and DOP pools are quite variable on a seasonal time scale. However, we believe that seasonal accumulation and concomitant enzymatic degradation of less degradable compounds such as phospholipids, mureic acid and chitin can account for these changes. In the cultures we cannot expect to detect this degradation during the short incubation period. Thus, while lacking conclusive information on the origin of the degradative enzymes the view of bacteria as poor remineralizers must be regarded with caution

The pool of UC either exists separately or constitutes the carbon backbone of the organic molecules that are included in the UN and UP pools. The concentration of $\mathrm{UC}$ in our cultures was $23 \mu \mathrm{M} \mathrm{C}$ of unknown composition. However, judging from the concentration of free carbohydrates in the oligotrophic Sargasso Sea $(10 \mu M C)$ it is possible that a major part of the UC was carbohydrates (Burney 1988). The $C: N$ ratio of the utilizable substrate $(39: 1)$ was actually higher than the in situ dissolved organic substrate (25:1) suggesting that the UC is low in nitrogen. In the cultures, bacteria grew with short generation times $(0.5$ to $1.7 \mathrm{~d})$ compared to in situ growth (3.6 d). This suggested growth on a substrate of fair quality although low in $\mathrm{N}$ and $\mathrm{P}$.

When nitrogen and phosphorus were added to the cultures, the consumption of DOC increased by $64 \%$ compared to the untreated cultures, and the yield of bacteria increased by $156 \%$. The P-limited cells (untreated and nitrogen-enriched cultures) showed a higher carbon consumption per produced cell (DOC consumption/yield of bacteria). This was first thought to reflect an effort by the cells to free more nutrients through high respiration, which would result in a lower growth efficiency [(yield of bacteria $\times$ POC)/DOC consumption]. However, POC data showed that although P-limited cells were fewer, they had a higher carbon content per cell (ca $54 \mathrm{fg} \mathrm{C}_{\text {cell }}^{-1}$ ) compared with nonlimited cells (ca $30 \mathrm{fg} C$ cell $^{-1}$ ). Consequently, the growth efficiency showed only minor differences between the cultures (Table 2). We believe that the higher POC values that were reached in limited cultures reflects the capability of bacteria to store carbon such as carbohydrates during $\mathrm{N}$ - and/or P-limiting conditions when cell division is no longer possible (Kanopka 1992). This is supported by the fact that when bacteria were grown with excess carbon (sucrose added, Villefranche experiment), during either $\mathrm{N}$ or $\mathrm{P}$ limitation, the cells increased in size (data not shown]. This was possibly caused by an increase in the amount of capsular material and/or grains of particulate matter, as observed in the microscope. Due to the fact that bacterial POC seemed to be a variable component, we do not want to put high emphasis on our determinations of growth efficiencies. Although the numbers correspond quite well with results found by other investigators, we did not measure respiration in our seawater cultures (Bjornsen 1986). We infer that the decrease of DOC in the filtrate might be a mislead- 
ing measure of growth efficiency unless proper measurements of all concerned parameters for bacterial growth (respiration, DOC decrease, POC and bacterial numbers) are available.

In order to study the flow of nutrients in a non-cut-off situation, diel studies in an intact microbial food web were performed in microcosms on 2 occasions. The population dynamics in the microbial food web, as seen in the diel experiments, showed a complex structure with an overall regulation (the sunlight) and a series of random influences that offset the balance between the predators and their prey. During fluctuating nutrient input (changes in remineralisation), the concentration of the limiting substrate may rise if the numbers and/or the activity of the consumers stay too low to assimilate the released nutrients. Uncoupling between bacterial growth and substrate supply may be caused by populations of grazing flagellates lagging behind the bacterial activity. As a result, heterotrophic bacteria and phototrophic organisms will experience pulses of nutrients which can be detected if the sampling interval is frequent enough as shown by Wheeler et al. (1989). Diel variations in phosphate, ammonium and carbon in microcosm experiments performed at Villefranche-sur-Mer suggested that the input of nutrients was pulsed and a high degree of correlation was found between these nutrient pulses and the level of bacterial yield. As a consequence, the level of utilizable phosphate (calculated as $\mathrm{P}$ incorporated in bacteria) also showed a sharp diel variation (more than $100 \%$ ). It is therefore obvious that the instantaneous values of utilizable substrate obtained from the seawater cultures should be regarded as a rough estimate. However, the seawater cultures demonstrated that bacterial growth depended on a high degree of inorganic nutrient utilization. This, and the correlation between nutrient levels and bacterial yield in the diel experiments, suggested that growth of heterotrophic bacteria was controlled by the supply of inorganic nutrients although the precise nature of this control is difficult to outline. Phosphate availability has been found to be important for the control of growth of heterotrophic bacteria in this and other studies (Currie \& Kalff 1984, Morris \& Lewis 1992). It was therefore interesting to consider the consequence of our results for the in situ turnover of nutrients. As calculated above, the bacterial production corresponded to a daily uptake of $0.017 \mu \mathrm{M}$ phosphorus and $0.18 \mu \mathrm{M}$ of nitrogen (calculated from the data of bacterial content in Table 3 ) which in turn corresponds to $52 \%$ and $30 \%$ of the utilizable pools respectively. Thus, the in situ pools of utilizable phosphorus and nitrogen have to be renewed at a rate of every $2 \mathrm{~d}$ for phosphorus and every $3 \mathrm{~d}$ for nitrogen in order to maintain the in situ bacterial production over time.
Acknowledgements. Excellent technical asistance by Åsa Rudehäll is acknowledged. This work was supported by the Swedish National Science Council. Marine facilities were provided by the Marine Sciences Center in Umeå. Our work in Villefranche-sur-Mer was much facilitated by the kind support of DrF. Rassoulzadegan.

\section{LITERATURE CITED}

Ammerman, J. W., Fuhrman, J. A., Hagström, ̊., Azam, F. (1984). Bacterioplankton growth in seawater: I. Growth kinetics and cellular characteristics in seawater cultures. Mar. Ecol. Prog. Ser. 18: 31-39

Ammerman, J. W., Azam, F. (1991). Bacterial 5'-nucleotidase activity in estuarine and coastal marine waters: role in phosphorus regeneration. Limnol. Oceanogr. 36: $1437-1447$

Azam, F., Smith, D. C. (1991). Bacterial influence on the variability in the ocean's biogeochemical state: a mechanistic view. In: Demers, S. (ed.) Particle analysis in oceanography. Springer-Verlag, Heidelberg, p. 213-236

Begon, M., Harper, J. L., Townsend, C. R. (1986). Ecology; individuals, populations and communities. Blackwell Scientific Publications. Oxford, p. 209-210

Bjørnsen, P. K. (1986). Bacterioplankton growth yield in continuous sea water cultures. Mar. Ecol. Prog. Ser. 30: $191-196$

Burney, C. M. (1986). Diel dissolved carbohydrate accumulation in coastal water of South Florida, Bermuda and Oahu. Estuar. coast. Shelf Sci. 23: 197-203

Burney, C. M. (1988). Bacterial utilization of total in situ dissolved carbohydrate in offshore waters. Limnol. Oceanogr. 31: $427-431$

Currie, D., Kalff, J. (1984). Can bacteria outcompete phytoplankton for phosphorus? Microb. Ecol. 10: 205-216

Fuhrman, J. A., Azam, F. (1982). Thymidine incorporation as a measure of heterotrophic bacterioplankton production in marine surface waters: evaluation and field results. Mar. Biol. 66: 109-120

Fuhrman, J. A., Eppley, R. W., Hagström, A., Azam, F. (1985). Diel variations in bacterioplankton, phytoplankton, and related parameters in the Southern California Bight. Mar. Ecol. Prog. Ser 27: 9-20

Fuhrman, J., Sleeter, T., Carlson, C. Proctor, L. (1989). Dominance of bacterial biomass in the Sargasso Sea and its ecological implications. Mar. Ecol. Prog. Ser. 57: 207-217

Goldman, J. C., Caron, D. A., Dennett, M. R. (1987). Regulation of gross growth efficiency and ammonium regeneration in bacteria by substrate C: $\mathrm{N}$ ratio. Limnol. Oceanogr. 32: $1239-1252$

Haas, L. W. (1982). Improved epifluorescence microscopy for observing planktonic micro-organisms. Annls Inst. océanogr., Paris 58: 261-266

Hagström, \&., Azam, F., Andersson, A., Wikner, J., Rassoulzadegan, F. (1988). Microbial loop in an oligotrophic pelagic marine ecosystem: possible roles of cyanobacteria and nanoflagellates in the organic fluxes. Mar. Ecol. Prog. Ser. 49: 171-178

Hagström, $\AA$, Larsson, U. (1984). Diel and seasonal variation in growth rates of pelagic bacteria. Plenum, New York, p. $249-262$

Hama, T., Matsunaga, K., Handa, N., Takahashi, M. (1988). Day-night changes in production of carbohydrate and protein by natural phytoplankton population from Lake Biwa, Japan. J. Plankton Res. 10: 941-955 
Heinänen, A., Kuparinen, J. (1992). Response of bacterial thymidine and leucine incorporation to nutrient $\left(\mathrm{NH}_{4}\right.$, $\mathrm{PO}_{4}$ ) and carbon (sucrose) enrichment. Arch. Hydrobiol. Beih. 37: 241-251

Hobbie, J. E., Daley, R. J., Jasper, S. (1977). Use of nucleporefilters for counting bacteria by fluorescence microscopy. Appl. environ. Microbiol. 33: 1225-1228

Horrigan, S. G., Hagström, §., Koike, I., Azam, F. (1988). Inorganic nitrogen utilization by assemblages of marine bacteria in sea water culture. Mar. Ecol. Prog. Ser. 50: 147-150

Kanopka, A. (1992). Accumulation of polysaccharide by hotspring phototrophs during a light-dark transition. FEMS Microbiol. Ecol. 102: 27-32

Lee, S., Fuhrman, J. (1987). Relationships between biovolume and biomass of naturally derived marine bacterioplankton. Appl. environ. Microbiol. 53: 1298-1303

Mopper, K., Lindroth. P. (1982). Diel and depth variations in dissolved free amino acids and ammonium in the Baltic Sea determined by shipboard HPLC analysis. Limnol. Oceanogr. 27: 336-347

Morris, D. P., Lewis, W. M. Jr (1992). Nutrient limitation of bacterioplankton growth in Lake Dillon, Colorado. Limnol. Oceanogr. 37: 1179-1192

Neidhardt, F. C., Ingraham, J. L., Schaechter, M. (1990). Physiology of the bacterial cell: a molecular approach. Sinauer Associates, Sunderland

Paul, J., DeFlaun, M. F., Jeffery, W., David, A. (1988). Seasonal and diel variability in dissolved DNA and in microbial biomass and activity in a subtropical estuary. Appl. environ. Microbiol. 54: 718-727

Porter, K. G., Feig, Y. S. (1980). The use of DAPI for identify-

This article was submitted to the editor ing and counting aquatic microflora. Limnol. Oceanogr. 31. 1010-1021

Riemann, B., Nielsen, P., Jeppesen, M., Marcussen, B. Fuhrman, J. (1984). Diel changes in bacterial biomass and growth rates in coastal environments, determined by means of thymidine incorporation into DNA, frequency of dividing cells (FDC), and microautoradiography. Mar. Ecol. Prog. Ser. 227-235

Straskrabova, V., Fuksa, J. (1982). Diel changes in numbers and activities of bacterioplankton in a reservoir in relation to algal production. Limnol. Oceanogr. 27: 660-672

Strickland, J. D. H. Parsons, T. R. (1972). A practical handbook of sea water analysis. Bull. Fish. Res. Bd Can. 167

Turk, V., Rhenstam, A.-S., Lundberg, E., Hagström, §. (1992). Release of bacterial DNA by marine nanoflagellates, an intermediate step in phosphorus regeneration. Appl. environ. Microbiol. 58: 3744-3750

Wheeler, P., Kirchman, D. (1986). Utilization of inorganic and organic nitrogen by bacteria in marine systems. Limnol. Oceanogr. 31: 998-1009

Wheeler, P., Kurchman, D., Landry, M., Kokkinakis, S. (1989). Diel periodicity in ammonium uptake and regeneration in the oceanic subarctic: implications for interactions in microbial food webs. Limnol. Oceanogr. 34: 1025-1033

Wikner, J., Rassoulzadegan, F., Hagström, §. (1990). Periodic bacterivore activity counterbalances bacterial growth in the marine environment. Limnol. Oceanogr. 35: 313-324

Williams, P. M. (1986). Chemistry of the dissolved and particulate phases in the water column. In: Eppley, R. W. (ed.) Plankton dynamics of the Southern California Bight. Springer-Verlag, Berlin, p. 53-83

Manuscript first received: February 12, 1993

Revised version accepted: July 28, 1993 